\title{
PERAN PEMERINTAH DALAM MENGANTISIPASI TERJADINYAPERSAINGAN USAHA TIDAK JUJUR BERDASARKANUNDANG-UNDANGNOMOR20TAHUN 2016 TENTANG MEREK DAN INDIKASI GEOGRAFIS
}

\author{
Oleh: Muhammad Ferdian \\ muhammadferdian89@gmail.com \\ Universitas Dirgantara Marsekal Suryadarma, Jakarta, Indonesia
}

\begin{abstract}
Business competition is often found whose business competition is dishonest, especially towards trademarks. In terms of minimizing the occurrence of violations of unfair business competition, the government has a very important role. The government needs to conduct socialization related to fair business competition on trademarks, by: conducting education, campaigns, providing understanding, providing training for of cers in the Directorate General of Intellectual Property, inviting the public in the ght against counterfeiting and imitation, and the existence of monitoring, evaluation, and fostering by the Directorate General of Intellectual Property or the Business Competition Supervisory Commission (KPPU) and conducting strict reprimands and legal sanctions for business actors who continue to violate their business activities and are proven, then Law Number 20 Year 2016 concerning Trademarks and Geographical Indications, speci cally regulates the provision of criminal sanctions that are included in the provisions of Articles 100 and 102.
\end{abstract}

Keywords: business competition; dishonest; KPPU; legal sanctions.

\section{PENDAHULUAN}

Dalam dunia bisnis saat ini, terjadipersainganusahayangcukupketat terutama dalam bisnis perdagangan suatu produk, dimana pelaku usaha berlomba-lomba mencari pasar dengan meningkatkan kualitas dan kuantitas produk yang mereka pasarkan, sehingga tujuan perusahaan tercapai yaitu mencarikeuntungan yang sebesar-besarnya. Bagi pelaku usaha harus jeli dan cermat dalam memahami perilaku pasar sehingga produk yang ditawarkan diterima oleh pasar sebagai konsumen.

Tidaksedikit masyarakat Indonesia dalam memilih produk dengan melihat brand (merek), apakah merek tersebut terkenal atau tidak. Dalam persepsi masyarakat sebagai konsumen bahwa merek yang terkenal merupakan jaminan mutu dan kualitas produknya, sehingga sebagian masyarkat yang mempunyai kemampuan financial akan memilihprodukdengan merek-merek terkenal tersebut dengan mengabaikan harga yang ditawarkan yang cukup mahal dan tidak jarang dalam kehidupan sosial masyarakat ada anggapan bahwa barang yang mereka pakai dengan menggunakan merek terkenal atau merek luar negeri, maka dapat menunjukkan status sosial mereka.
Begitu pentingnya peran merek dalam kegiatan bisnis, maka tidak sedikit para pelaku usaha memanfaatkan peluang usaha tersebut untuk membuat produk dengan merek-merek terkenaltanpa mempedulikan persoalan hukum dan pihak-pihak yang dirugikan akibat yang mereka lakukan. Produk yang ditawarkan oleh para pelaku usaha tersebut misalkan dengan merek yang sama atau adanya kemiripan akan tetapi mempunyai kualitas yang berbeda ataupun dapat mengacaukan publik berkenaan dengan sifat dan asal usul merek, seperti halnya contoh dibawah ini :

1. Pemalsuan merek dagang, salah satu contoh merek adidas diganti dengan merek adidas. (persamaan keseluruhan keseluruhan atau merek indentik)

Pengusaha yang tidak beritikad baik itu dengan memproduksi barang-barang dengan memper- gunakan merek yang sudah dikenal secara luas di dalam masyarakat yang bukan merupakan haknya. Dengan tujuan pengusaha mengharap- kan memperoleh keuntungan yang besartanpa mengeluarkan biaya untuk 
memperkenalkan merek tersebut kepada masyarakat karena 
merek tersebut sudah dikenal oleh masyarakat dan tampaknya merek adidas memberikan kesan berkelas dan bergengsi sehinga banyak konsumen membelinya.

2. Peniruan merek dagang seperti salah satu contoh merek Levi's diganti dengan merek Levi. (Persamaan pada pokoknya)

Merek Levi's yang sudah terkenal di masyarakat atas mutu, kualitasnya tersebut oleh pelaku usaaha yang bergerak di bidang konveksi membuat atau memproduksi merek Levi. Pen- gusaha yang beritikad tidak baik, persaingan tidak jujur semacam ini berwujud penggunaan atau menggunakan merek dengan meniru merek terkenal (wel know trade mark) yang sudah ada sehingga merek atas barang atau jasa yang sudah terkenal, dengan maksud menimbulkan kesan kepada khalayak ramai, seakan-akan barang atau jasa yang diproduk- sinya itu sama dengan produksi barang atau jasa yang sudah terkenal itu. Adapun tujuan pengusaha tersebut dengan adanya kemiripan tersebut, dapat memperoleh keuntungan yang besar tanpa mengeluarkan biaya besar untuk promosi memperkenalkan produknya tersebut. Hal ini karena konsumen dapat dikelabuhi dengan kemiripan merek tersebut.

3. Perbuatan-perbuatan yang dapat mengacaukan publik berkenaan dengan sifat dan asal usul merek, salah satu contoh merek Kopi Gayo menjadi Gayo Mountain Coffe.

Kopi Gayo di mana merek dagang tersebut di klaim milik sebuah perusahaan perdagangan asal Belanda sebagai pemegang hak yang notabene Kopi Gayo tersebut adalah khas dari NanggroeAceh Darussalam. Perusahaan asal Belanda tersebut (Holland Coffe B.V) mengklaim bahwa perusahaan tersebut merupakan pemilik dari hak merek dagang kopi tersebut dan terdaftar di dunia internasional dengan nama Gayo Mountain coffee.
Dari tindakan-tindakan tersebut dimana pelaku usaha dalam menjalankan kegiatan usahanya tidak jujur artinya pelaku usaha tersebut menarik pelanggan (konsumen) untuk membeli produk atau jasa kepada 
perusahaan demi untuk mendapatkan pendapatan (omzet) yang besar dengan menggunakan cara-cara yang bertentangan dengan itikad baik dan kejujuran di dalam perdagangan.Sehingga tidak jarang para konsumen menggunakan beberapa produk dengan merek yang sama atau mirip tetapi kualitasnya ber- beda. Pelanggaran-pelanggaran yang terjadi dunia usaha, baik di dalam negeri maupun di luar negeri tersebut merupakan bukti betapa pentingnya peran merek dalam dunia usaha. Banyaknya modus pelaku usaha atau produsen yangmensiasati dengan cara mengkombinasikan barang-barang bermerek yang aslidengan yang palsu, secara fisik benarbenarmirip dengan yang asli.

Memang sebagian masyarakat sebagai kon- sumen mengetahui merek yang pakai palsu, sebab mer- upakan daya tarik bagi konsumenyang secara finansial pas-pasan tetapi ingintampil trendi.Ada banyak cara untuk memenuhi kebutuhan gaya hidup,salahsatunya adalah dengan membeli barang-barangbermerek (mer- ek terkenal). Barang-barang denganmerek tersebut tentunya selalu dibandrol dengan harga yang tinggi. Akhirnya,masyarakat seringkali mengambil jalan pintas dengan membeli versi palsu darimerek tersebut agar tetap terlihat bergaya.Produk-produk bermerek (luxrury good) asli tapi palsu (aspal) sepertibaju, celana, sepatu dan berbagai asesoris lainnya sangat mudah didapat dan ditemukan di kota-kota besar, peredarannyapun meluas mulai dari kaki limasampai pusat pertokoan bergengsi. Salah satu daya tarik dari produk bermerekpalsu memang terletak pada harganya yang sangat murah. Peredaran barangbarang aspal tersebut diiringi pula dengan pemanfaatan barang tersebut olehkonsumen. Konsumen yang mengedepankan gaya hidup tidak pernah memandangbarang yangdigunakan asli atau palsu tetapi yang dilihat adalah barang denganmerek yang sama dan harganya terjangkau.

Tetapi bagaimana bagi masyarakat yang ingin membeli produk asli tetapi yang dibeli malah produk palsu, hal ini tentu saja merugikan konsumen karena merasa tertipu oleh suatu produk dan kerugian bagi pengusaha atau perusaahaan yang merek produknya di palsukan, kerugian tersebut baik secara finansial maupun image di masyarakat yang selama ini mereka bangun. 
Adapun alasan mengapa banyak industri memanfaatkan merek-merek terkenal untuk produkproduknya,yangpertamasecara ekonomi memanfaatkan merek terkenal mendatangkankeuntungan yang cukup besar dan fakta dilapangan membuktikan hal tersebut.Yang kedua dengan memanfaatkan merek terkenal agar mudah dijual, selain itu merek tidakperlu repot-repot mengurus nomor pendaftaran ke Dirjen HaKI atau mengeluarkan uang jutaan rupiah untuk membangun citra produknya (brand image). Mereka tidak perlu repot repot membuat divisi riset dan pengembangan untuk dapat menghasilkan produk yang selaluup to date, karena mereka tinggalmenjiplak produk orang lain dan untuk pemasarannya biasanya "bandar" yang siap untuk menerima produk jiplak tersebut.

Disinilahperan pemerintah sangat dibutuhkan dalam menanggulangi tindakan-tindakan pelaku usaha yang tidak jujur atau persaingan usaha tidak sehat, melalui instrumen hukum, kebijakan-kebijakan hukum dalam persaingan usaha yang baik atau jujur. Saat ini pemerintah dalam mengatur terkait dengan persaingan usaha yaitu melalui Undang-Undang Nomor 20 Tahun 2016 tentangMerek Dan Indikasi Geografis, adapun yang menjadi pertimbangan utama dikeluarkan undang-undang ini adalah

"bahwa di dalam era perdagangan global, sejalan dengan konvensi intemasional yang telah diratifikasi Indonesia, peranan Merek dan Indikasi Geografis menjadi sangat penting terutama dalam menjaga persaingan usaha yang sehat, berkeadilan, pelindungan konsumen, serta pelindungan Usaha Mikro, Kecil, dan Menengah dan industri dalam negeri". ${ }^{1}$

Berdasarkan pertimbangan tersebut di atas, dengan undang-undang tersebut dibuat untuk menjaga persaingan usaha yang sehat, dalam artian bahwa undang-undang melarang persaingan usaha tidak sehat atau tidak jujur. Berdasarkan alasan tersebut, penulis tertarik mengkaji lebih dalam mengenai "Peran Pe- merintah Dalam Mengantisipasi Terjadinya Per- saingan Usaha Tidak Jujur Berdasarkan Undang- UndangNomor20Tahun 2016 TentangMerek Dan Indikasi Geografis".

1 Undang-Undang Nomor 20 Tahun 2016 tentang Merek Dan Indikasi Geografis, Menimbang a.

\section{RUMUSAN PERMASALAHAN}

Berdasarkan permasalahan tersebut, maka rumusan masalah penelitian ini adalah sebagai berikut :

1. Bagaimana upaya pemerintah dalam mensosialisasikan persaingan usaha yang sehat terhadap merek dagang ?

2. Bagaimana upaya pemerintah dalam melakukan tindakan hukum terhadap pelaku usaha yang tidak jujur berdasarkan Undang-Undang Nomor 20 Tahun 20016 tentang Merek Dan Indikasi Geografis?

\section{METODE PENELITIAN}

Metode penelitianini menggunkan penelitian hukum yuridis normatif yang termasuk jenis pene- litian, dimana didalamnya penulis meneliti norma yang terdapat dalam peraturan perundang-undan- ganyang mengatur tentang perlindungan hukum merek dagang dan bukubuku sebagai acuan. Jadi dalam penelitian hukum normatif untuk mema- hami adanya hubungan antara ilmu-ilmu hukum dengan hukum positif.Sumber data yang berasal dari sumber primer dan sumber sekunder.

\section{PERSAINGAN USAHA TIDAK JUJUR}

Dalam dunia bisnis sering terjadi yang namanya persaingan usaha. Dalam konteks secara teoritis hukum persaingan usaha dapat dimaknai dengan dua bahasan kata, yakni hukum dan persaingan usaha. Dalam mekanisme hukum dimana para pelaku usaha dalam menjalankan kegiatan usahanya hendaklah bersaing secara sehat dengan berpedomankepadaundangundang yang berlaku. Dalam menjaga persaingan tetap sehat maka diperlukan seperangkat hukum yang mengatur tentang etika berbisnis yang baik. Pemerintah telah mengeluarkan kebijakan-kebijakan persaingan usaha yang dikelola dengan lembaga khusus yang namanya Komisi Pengawas Persaingan Usaha (KPPU). KPPU merupakan suatu lembaga yang independen dalam menangani, memutuskan dan atau melakukan penyelidikan suatu perkara tidak dapat dipengaruhi oleh pihak manapun. 
Terkait dengan kebijakan hukum persaingan usaha, menurut Hermansyah, adalah : "Kebijakan 
yang berkaitan dengan masalah-masalah di bidang persaingan usaha yang harus dipedomani oleh pelaku usaha dalam menjalankan kegiatan usahanya dan melindungi kepentingan konsumen". ${ }^{2}$

Lebih lanjut lagi Hermansyah mengatakan bahwa : "Yang dimaksud dengan hukum persaingan usaha adalah seperangkat aturan hukum yang mengatur mengenai segala aspek yang berkaitan dengan persaingan usaha, yang mencakup hal-hal yang boleh dilakukan dan hal-hal yang dilarang dilakukan oleh pelaku usaha". ${ }^{3}$

Tetapi dalam implementasinya dalam kegiatan usaha terjadinya pelanggaran-pelanggaran yang dilakukan oleh pelaku usaha seperti pelaku usaha tersebut dalam menjalankan usaha tidak sehat atau persaingan usaha tidak jujur, secara khusus mengenai aturan persaingan usaha tidak sehat diatur dalam Undang-Undang Nomor 5 Tahun 1999 tentang Larangan Praktek Monopoli Dan Persaingan Usaha Tidak Sehat, hal ini termuat dalam Pasal 1 angka 6 bahwa :

Persaingan usaha tidak sehat adalah persaingan antar pelaku usaha dalam menjalankan kegiatan produksi dan atau pemasaran barang dan atau jasa yang dilakukan dengan cara tidak jujur atau melawan hukum atau menghambat persaingan usaha. ${ }^{4}$

Persaingan usaha tidak jujur, yang dilakukan oleh para pelaku usaha dilanjukan dengan banyak cara salah satunya terkait masalah Hak Kekayaan Intelektual dalam bidang merek.Maka demi mendapat perlindungan hukum atas merek dagang, pemerintah secara konsisten melakukan perubahan atas peraturan perundang-undangan merek.Persaingan tidak jujur (Unfair competition) sangatlah tidak diharapkan terjadi. Pasal 10bis dari Konvensi Paris memuat ketentuan bahwa negara peserta Uni Paris terikat untuk memberikan perlindungan yang efektif agar tidak terjadi persaingan yang tidak jujur.

Memang secara implisit dalam Undang-Undang Nomor 20 Tahun 2016 tentang Merek Dan Indikasi Geografis tidak diatur mengenai persaingan tidak jujur, hanya mengatur merek yang mempunyai kesamaan secara keseluruhan, kesamaan pada pokoknya dan 2 Hermansyah, Pokok-pokok Hukum Persaingan Usaha di Indonesia, Jakarta : Kencana Prenada Media Group, 2008, hal. 2. 3 Loc.cit.

4 Undang-Undang Nomor 5 Tahun 1999 tentang Larangan Praktek Monopoli Dan Persaingan Usaha Tidak Sehat, Pasal 1 angka 6. dapat mengacaukan publik atas asal usul maka permohonannya dapat ditolak dan bagi yang melanggar dapat dikenakan sanksi pidana.

Menurut Sudargo Gautama, yang dimaksud dengan persaingan usaha tidak jujur adalah:

"Usaha untuk melawan konkurensi curang ini dan iktikad buruk dalam peniruan merek-merek adalah hanya demi kepentingan daripihak pemilik merek asing luar negeri dari negaranegara yang industrinya sudah maju. Bukan karena alasan tersebut tetapi lebih tepatnya kepada kepentingan dari pada masyarakat negara berkembang sendiri yang akan memperoleh lebih banyak perlindungan terhadap adanya barang-barang tiruan atau pemalsuan yang sungguhnya merugikan ini". ${ }^{5}$

Dari pendapat Sudargo Gautama tersebut dapat diambil kesimpulan bahwa untuk melindungi merekmerek terkenal ini sesungguhnya yang akan mencari korban adalah khalayak ramai sendiri dari negaranegara yang sedang berkembang ini. Masyarakatlah yang akan merugi karena membeli barang palsu sebab kualitas merek palsu tidak terjamin.

Menurut Molegraf dalam R.M. Suryodiningrat persaingan tidak jujur adalah :

"Peristiwa di dalam mana seseorang untuk menarik para pelanggan orang lain kepada perusahaan dirinya sendiri atau demi perluasan penjualan omzet perusahaannya, menggunakan cara-cara yang bertentangan dengan itikad baik dan kejujuran di dalam perdagangan". ${ }^{6}$ Menurut Muhammad Djumhana dan R. Djubaedillah, mengenai persaingan tidak jujur menyebutkan :

"Suatu perbutan yang dapat menciptakan kekeliruan dengan cara apa pun berkenaan dengan asal usul barang atau berkenaan dengan usaha-usaha indistrial dan komersial dari seorang pengusaha yang bersaingan"

\footnotetext{
5 Sudargo Gautama, Op.cit., hal. 140. 6 R.M. Suryodiningrat, Aneka Hak Milik Perindustrian, Bandung : Tarsito, 1981, hal. 66. 7 Muhamad Djumhana, Hak Milik Intelektual, Sejarah, Teori dan Prakteknya di Indoneia, Bandung : Citra Aditya Bakti, 2003, hal. 202.
} 
Menurut AnneGunawati, menyebutkan bahwa: "Persaingan usaha tidak sehat tersebutdilandasi oleh adanya iktikad buruk daripelaku usaha untuk mendapatkan keuntungan dengan cara melanggar hakorang lain di bidang HKI khususnyamerek. ${ }^{8}$

\section{HASIL DAN PEMBAHASAN}

\section{Upaya Pemerintah Dalam Mensosialisasikan} Persaingan Usaha Yang Sehat Terhadap Merek Dagang

Dalam rangka menuju era globalisasi ekonomi atau sering disebut era perdagangan bebas tingkat dunia, menyebabkan Indonesia harus membuka pasar bebas dalam negeri agar produk barang dan/atau jasa dari luar dapat masuk dan bersaing dengan barang dan/ atau jasa dalam negeri. Begitupun sebaliknya bahwa produk Indonesia dapat masuk dan bersaing di pasar luar negeri.Persaingan dalam dunia usaha, sebagian pelaku usaha sebagai motivasi untuk membangkitkan gairah menciptakan kualitas barang yang bermutu, pelayanan konsumen yang baik, tingkat harga yang pantas, pengusaha yang bukan semata-mata mengejar profit motive, keuntungan perusahaan yang wajar, akumulasi kekayaan bukan dari margin keuntungan yang tinggi, tetapi dari omzet penjulaan dengan proses perputaran cepat.

Jadi persaingan usahadalam kegiatan bisnis merupakan hal yang wajar apabila persaingan usaha dengan sehat. Pemerintah melakukan pengawasan terhadap persaingan usaha melalui Komisi Pengawasan Persaingan Usaha (KPPU) yang merupakan komisi negara dan lembaga penegak hukum independen terhadap praktik persaingan usaha dan pemberi saran kebijakan persaingan. Bebas dari pengaruh dan kontrol pemerintah maupun pihak manapun yang diatur melalui Undang-Undang Nomor 5Tahun 1999 tentang Larangan Praktik Monopoli dan Persaingan Usaha Tidak Sehat.

Tetapi dalam penelitian ini membahas dan menganalisis masalah merek dagang terkenal yang dalam implementasi dunia bisnis saat ini banyak terjadi pelanggaran-pelanggaran yang dilakukan oleh para 8 AnneGunawati,Perlindungan Merek Terkenal Barang danJasa Tidak Sejenis Terhadap Persaingan UsahaTidak Sehat, Bandung : Alumni, 2015, hal. 267. pelaku usaha demi memperoleh keuntungan yang besar tanpa melihat kerugian-kerugian yang diderita akibat tindakannya tersebut. Merek dagang yang di palsukan, ditiru dan perbuatan yang mengacaukan publik berkenaan dengan sifat dan asal usul merek yang mengacu pada ketentuan Undang-Undang Nomor 20 Tahun 2016 tentang Merek Dan Indikasi Geografis. Merek mempunyai peran penting dalam kegiatan bisnis, dimana merek sebagai suatu tanda (sign) untuk membedakan barang-barang atau jasayang dihasilkan oleh perusahaan atas jaminan, kualitas sebuah merek dalam perdagangan barang atau jasa. Pandangan masyarakat (konsumen) dengan kehadiran teknologi dan informasi yang terbuka saat ini, membuat konsumen lebih jeli dan teliti dalam menilai kualitas merek suatu barang. Tetapi juga kehadiran teknologi dan informasi saat ini dimanfaatkan oleh sebagian para pelaku usaha dalam memasarkan produknya dengan cara-cara yang tidak jujur seperti :

1. Pemalsuan merek dagang, salah satu contoh merek adidas disamakan dengan merek adidas. (Persamaan secara keseluruhan (merek indentik)

2. Peniruan merek dagang seperti salah satu contoh merek Levi's diganti dengan merek Levi. (Persamaan pada pokoknya)

3. Perbuatan-perbuatan yang dapat mengacaukan publik berkenaan dengan sifat dan asal usul merek, salah satu contoh merek Kopi Gayo menjadi Gayo Mountain Coffe.

Pelanggaran-pelanggaran yang dilakukan oleh para pelaku usaha tersebut merupakan sebagian contoh yang terjadi di masyarakat terkait dengan pelanggaran merek dagang. Hal ini merupakan bagi para pelaku usaha yang merek dagangnya ditiru, dipalsukan atau dikacaukan terkait sifat dan asal usul merek secara indikasi geografis. Perbuatan melanggar hukum tersebut dan mungkin juga melanggar norma-norma sopan santun, moral dan norma-norma sosial lainya dalam lalu lintas perdagangan, maka persaingan itu dapat menjurus pada persaingan usaha tidak jujur. Motivasi pelanggaran terhadap merek adalah untuk mendapatkan keuntungan pribadi secara mudah dengan mencoba atau melakukan tindakan, meniru atau memalsukan merek-merek yang sudah terkenal di masyarakat tanpa 
memikirkan hak-hak orang lain yang hak-haknya telah dilindungi sebelumnya. Tentu saja hal-hal demikian ini akan sangat mengacaukan roda perekonomian dalam skala nasional dan internasional.

Maka perlu adanya kebijakan-kebijakan hukum dalam menghadapi persaingan usaha. Hukum persaingan usaha yang mendukung sistem ekonomi pasar diciptakan agar persaingan antar pelaku usaha tetap dinamis, bersaing, serta dilakukan secara wajar dan sehat, selebihnya konsumen jangan dieksploitasi oleh pelaku usaha. Adapun upaya pemerintah dalam mensosialisasikan persaingan usaha yang sehat terhadap merek dagang melalui pendekatan hukum. Konsekuensi hukum yang terjadi dalam koridor penegakan hukum persaingan usaha yaitu yang dikenal dengan pendekatan hukum yang didasarkan pada kriteria pembuktian substantif. Apakah perbuatan tersebut melanggar ketentuan Undang-Undang Nomor 20 Tahun 2016 tentang Merek Dan Indikasi Geografis, terkait masalah persamaan secara keseluruhan, persamaan pada pokoknya atau membingungkan publik atas asal usul merek tersebut.

Pemerintah perlu melakukan sosialisasi terkait persaingan usaha yang sehat terhadap merek dagang, dengan cara :

1. Melakukan edukasi secara mendasar kepada masyarakat khususnya pelaku usaha, apabila dalam menjalankan kegiatan usahanya berkewajiban untuk mendaftar merek dagangnya dan memberikan pemahanan terkait masalah pentingnya merek dalam sebuah organisasi perusahaan.

Setiap orang atau organisasi perusahaan yang ada, akan sangat pentingnya sebuah nama atau simbol yang digunakan dalam menjalankan kegiatan bisnis dan pemasaran produk. Merek tersebut akan menunjukkan asal barang, serta perusahaan bidang usahanya, dan nama peru- sahaan. Merek sebagai sarana periklanan untuk memperkenalkan merek yang diperdagangkan dalam perusahaan, jadi merek merupakan ujung tombak perdagangan barang, melalui merek pengusaha dapat menjaga dan mem- berikan jaminan akan kualitas (a quaratee of quality) barang yang dihasilkan dan mence- 
gah tindakan persaingan yang tidak jujur dari pengusaha lain yang beriktikad buruk yang bermaksud membonceng reputasinya.

Dengan melakukan pendaftarkan merek maka merek dagang yang sudah didaftarkan mendapat per- lindungan selama 10 (sepuluh) tahun sejak tanggal penerimaan sesuai dengan Pasal 35 ayat (1) dan dapat diperpanjang untuk jangka waktu yang sama sesuai Pasal 35 ayat (2) Undang-Undang Nomor 20 Tahun 2016 tentang Merek Dan Indikasi Geografis, sehingga ini memberikan kepastian hukum terhadap pemegang merek terdaftar.

2. Melakukankampanye-kampanye mengenai pelanggaran merek atau larangan menggu- nakan merek orang lain atau merek terkenal dengan cara-cara :

a. Persamaan secara keseluruhan, artinya merek yang memiliki persamaan secara ke- seluruhan (identical marks) ada, apabila tanda memiliki persamaan secara keseluruhan dengan merek dan diterapkan untuk produk sejenis yang telah dilindungi lebih dahulu (identical mark and identical product-double identity) dan perbuatan dapat dikatakan pe- malsuan (counterfeititng), seperti merek ad-didas dipalsukan addidas.

b. Persamaan pada pokoknya yaitu kemiri- pan yang disebabkan oleh adanya unsur-unsur yang menonjol antara merek yang satu dengan merek yang lain, yang dapat menimbulkan kesan adanya persamaan baik mengenai bentuk, cara penempatan, bunyi ucapan atau persamaan arti yang terdapat dalam merek tersebut, seperti merek Levi's diganti dengan merek Levi.

Merek addidas dan Levi'smerupakan merek terkenal di negaranya. Larangan menggunakan merek- merek terkenal yang sudah diakui keberadaannya oleh masyarakat. Merek terkenal terkait dengan per- lindungan atas reputasi dan Doctrin Dilution daalam Thomas Mc. Carthy, ada tiga hal yang harus ditunjuk- kan yaitu
1. Merek merupakan merek terkenal atau memiliki reputasi (trade mark is well-known or has reputasion). 
2. Merek memiliki persamaan pada pokoknya khususnya untuk barang yang tidak sejenis (similarity of trademark but goods and services are dissimilar).

3. Ada penggunaan yang bersifat penipisan, pemudaran, dan pengaburan secara tanpa hak (the is dilution or tarnishment or blurring reputation without due cause). ${ }^{9}$

Bagi pelaku usaha yang memakai merek terkenal harus mendapatkan lisensi atas merek terkenal tersebut. Yang dimaksud dengan lisensi menurut Pasal 1 angka 18 Undang-Undang Nomor 20 Tahun 2016 tentang Merek dan Indikasi Geografis adalah :

Lisensiadalah izin yang diberikan oleh pemilik Merek terdaftar kepada pihak lain berdasarkan perjanjian secara tertulis sesuai peraturan perundangundangan untuk menggunakan Merek terdaftar. ${ }^{10}$

Pemilik merek terdaftar dapat memberikan mereknya kepada pihak ketiga ssuai dengan perjanjian secara tertulis untuk digunakan sesuai dengan isi perjanjian hal ini dipertegas dengan ketentuan Pasal 42 ayat (1) Undang-Undang Nomor 20 Tahun 2016 tentang Merek Dan Indikasi Geografis bahwa :

Pemilik Merek terdaftar dapat memberikan Lisensi kepada pihak lain untuk menggunakan Merek tersebut baik sebagian maupun seluruh jenis barang dan/atau jasa. ${ }^{11}$

3. Memberikan pemahanan kepada masyarakat terkait masalah sistem hukum merek dalam melindungi produk indikasi geografis.

Dalam TRIPs Indikasi Geografis diatur dalam Article 22 dan 23 TRIPs. Indikasi geografis, yang dimaksud dalam Persetujuan TRIPs adalah indikasi yang mengidentifikasi barang berasal dari wilayah negara Anggota Perjanjian, atau dari region atau lokalitas tertentu di wilayah tersebut, dimana suatu kualitas, reputasi atau karakteristik positif lainnya pada dasarnya bersumber dari geografis asal yang dimaksud. Dalam aturan hukum merek di Indonesia diatur dalam Undang-Undang Nomor 20 Tahun 2016

9 Thomas Mc. Carthy, Trademark and Unfair Competition, 4ed., US : West Group, 2000, hal. 20.20.1.

10 Undang-Undang Nomor 20 Tahun 2016, Op.cit., Pasal 1 angka 18.

11 Ibid., Pasal 42 ayat (1) tentang Merek Dan Indikasi Geografis, yaitu indikasi geografis mempunyai perlindungan hukum apabila sudah didaftarkan oleh Menteri, untuk itu perlu dilakukan permohonan pendaftaran indikasi geografis, hal ini dipertegas dengan ketentuan Pasal 53 ayat (1) dan (2). Adapun yang boleh melakukan pemohonan sesuai dengan ketentuan Pasal 53 ayat (3) Undang-Undang Nomor 20 Tahun 2016 tentang Merek Dan Indikasi Geografis, adalah :

a lembaga yang mewakili masyarakat di kawasan geografis tertentu yang mengusahakan suatu barang dan/atau produk berupa:

1. sumber daya alam; 2. barang kerajinan tangan; atau 3. hasil industri.

b. pemerintah daerah provinsi atau kabupaten/ kota. $^{12}$

Maka apabila terjadi pelanggaranpelanggaran atas indikasi geografis, bagi yang merek indikasi geografisnya terdaftar di Direktorat Jenderal Kekayaan Intelektual, dapat melaku- kan gugatan.

4. Mengadakanpelatihan-pelatihanyangdifokuskan bagi para pemeriksa merek serta Penyidik Pegawai Negeri Sipil (PPNS) Direktorat Jenderal Kekayaan Intelektual.

5. Mengajak Masyarakat Indonesia Anti Pemalsuan untuk berdiskusi hal kongkritterkait penanganan terhadap pembajakan serta pemalsuan merek terdaftar.

6. Adanya pemantauan, evaluasi, dan pembinaan oleh pejabat terkait seperti Direktorat Jenderal Kekayaan Intelektual dan Komisi Pengawasan Persaingan Usaha (KPPU).

7. Melakukan teguran dan sanksi hukum secara tegas bagi para pelaku usaha yang tetap melakukan pelanggaran terhadap kegiatan usahanya.

Apabial upaya-upaya tersebut dilakukan oleh pemerintah maka, tidak menutup kemungkinan bahwa persaingan usaha dalam dunia bisnis berjalan dengan jujur dan dapat menimimalisasi terjadinya persaingan usaha tidak jujur. 
12 Ibid., Pasal 53 ayat (3). 
2 Upaya Pemerintah Dalam Melakukan Tindakan Hukum Terhadap Pelaku Usaha Yang Tidak Jujur Berdasarkan Undang-Undang Nomor 20 Tahun 20016 Tentang Merek Dan Indikasi Geografis

Indonesia sebagai negara yang tergabung kedalam organisasi perdagangan dunia yakniWorld TradeOrganization (WTO) yang melahirkan suatu kesepakatan bersama dalam bidang Hak Kekayaan Intelektual(intellectual property rights) dengan produk perjanjian bernama Trade Related Aspect of Intellectual Property Rights(TRIPs) telah memberikan perlindungan hukum atas sebuah merek dagang. Maka sejalan dengan konvensi internasional yang telah diratifikasi Indonesia.Pemerintah melalui Undang-Undang Nomor 20 Tahun 2016 tentang Merek Dan Indikasi Geografis, telah memberikan perlindungan hukum dan kepastian hukum dalam menjaga persaingan usaha yang sehat, berkeadilan, pelindungan konsumen, serta pelindungan Usaha Mikro, Kecil, dan Menengah dan industri dalam negeri.

Maka dari itu apabila dalam kegiatan bisnis, terjadi pelanggaran-pelanggaran yang dilakukan oleh pelaku usaha yang tidak bertanggungjawab atau dalam menjalankan kegiatan usahanya tidak jujur, ssuai dengan ketentuan Pasal 94 Undang Nomor 20 Tahun 2016 tentang Merek Dan Indikasi Geografis, berdasarkan bukti permulaan yang cukup, pemilik merek terdaftar haknya dirugikan dapat meminta hakim Pengadilan Niaga untuk menerbitkan surat penetapan sementara tentang:

a pencegahan masuknya barang yang diduga hasil pelanggaran Hak atas Merek ke jalur perdagangan;

b. penyimpanan alat bukti yang berkaitan dengan pelanggaran Hak atas Merek tersebut;

c. pengamanan dan pencegahan hilangnya barang bukti oleh pelanggar; dan/atau

d. penghentian pelanggaran guna mencegah kerugian yang lebih besar. ${ }^{13}$

Disamping itu pemilik merek terdapat dapat melaporkan pelanggaran tersebut kepada pihak penyidik Polri dan/ataupejabat Penyidik Pegawai

13 Ibid., Pasal 94.
Negeri Sipil tertentu dilingkungan kementerian yang menyelenggarakan urusan pemerintahan di bidang hukum diberi wewenang khusus sebagai penyidik sebagaimana dimaksud dalam UndangUndang yang mengatur mengenai hukum acara pidana (KUHAP) untuk melakukan penyidikan tindak pidana Merek. Maka atas pelaporan tersebut aparat penegak hukum melakukan tindakan penyelidikan dan penyidikan. Sebab dalam tindak pidana tersebut merupakan delik aduan, hal ini dipertegas dengan ketentuan Pasal 103 Undang-Undang Nomor 20 Tahun 2016 tentang Merek Dan Indikasi Geografis. Apabila pelanggaran tersebut terbukti, makaUndang-Undang Nomor20Tahun2016tentang Merek Dan Indikasi Geografis, secara khusus mengatur pemberian sanksi pidana yaitu termbuat dalam ketentuan Pasal 100 dan 102, yang mengatur pelanggaran-pelanggaran persaingan usaha tidak jujur atau tidak sehat yang dapat dikategorikan dalam tiga area utama yaitu :

1. Persamaan secara keseluruhan (merek identik)

Persamaan secara keseluruhan dengan merek terkenal milik pihak lain untuk barang dan/atau jasa yang sejenis dilakukan dengan memperhatikan pengetahuan umum masyarakat mengenai merek tersebut di bidang usaha yang sama. Dalam hal ini persaingan tidak jujur tersebut dilakukan oleh pengusaha yang tidak beriktikad baik itu dengan cara memproduksi barang-barang dengan mempergunakan merek yang sudah dikenal secara luas di dalam masyarakat yang bukan merupakan haknya. Dalam hal ini juga maka pengusaha itu tentunya sangat berharap memperoleh keuntungan besar karena merek terkenal yang diperdagangkan sudah dikenal oleh masyarakat. Dalam Undang-Undang Nomor 20 Tahun 2016 tentang Merek dan Indikasi Geografis, apabila merek mempunyai persamaan secara keseluruhan (identik) maka berdasarkan ketentuan Pasal 21 dalam permohonan pendaftaran merek, maka permohonan tersebut akan ditolak. Sebab merek harus memiliki daya pembeda (distintiveness) dapat diuji ketika fase pendaftaran melalui prosedur keberatan, atau ketika dalam jangka waktu perlindungan merek terdaftar melalui prosedur pembatalan dalam uji keabsahan hak merek terdaftar 
atau ketika disinyalir ada tindak pidana atau adanya pelanggaran yang dilakukan bagi pelaku usaha dalam membuat atau pemberdagangkan produk terlihat ada persamaan secara keseluruhan (identik), maka dapat diterapkan ketentuan pidana sesuai dengan Pasal 100 ayat (1) Undang-Undang Nomor 20 Tahun 2016 tentang Merek Dan Indikasi Geografis, yang merumuskan bahwa :

Setiap Orang yang dengan tanpa hak menggunakan Merek yang sama pada keseluruhannya dengan Merek terdaftar milik pihak lain untuk barang dan/atau jasa sejenis yang diproduksidan/ataudiperdagangkan, dipidana dengan pidana penjara paling lama 5 (lima) tahun dan/atau pidana denda paling banyak Rp. 2.000.000.000,00 (dua miliar rupiah). ${ }^{14}$

Berdasarkan ketentuan Pasal 100 ayat (1) di atas, setiap orang yang dengan tanpa hak menggunakan merek yang sama pada keseluruhannya dengan merek terdaftar milik pihak lain atau dengan kata lain memalsukan merek dagang orang lain maka dapat dipidana dengan pidana penjara paling lama 5 (lima) tahun dan/atau pidana denda paling banyak Rp. 2.000.000.000,00 (dua miliar rupiah).

Menanggapai maksud dari persaingan tidak jujur terkait masalah merek, dimana pelaku usaha dalam menjalankan kegiatan usahanya dengan cara-cara melanggar aturan atau ketentuan yang diatur dalam Undang-Undang Merek dan Indikasi Geografis dan hanya untuk memperoleh keuntungan dirinya sendiri, tidak memikirkan hak-hak orang lain yang diganggu. Cara-cara yang dilakukan oleh pelaku usaha tersebut dengan cara meniru dan memalsukan merek yang sudah terkenal di masyarakat, sehingga tidak perlu susah payah untuk promosikan atas barang yang mereka perdagangkan.

\section{Persamaan pada pokoknya}

Pengusaha yang beriktikad tidak baik tersebut dalam hal persaingan tidak jujur, berwujud penggunaan upaya-upaya atau ikhtiar-khtiar mempergunakan merek dengan meniru merek terkenal (well know trade mark) yang sudah ada sehingga merek atas barang yang diproduksinya secara pokoknya sama dengan

14

Undang-Undang Nomor 20 Tahun 2016, Op.cit., Pasal 100 ayat (1). mereka atas barang yang sudah terkenal dan barang sejenis dengan maksud menimbulkan kesan kepada khalayak ramai, seakan-akan barang atau jasa yang diproduknya itu sama dengan produk yang sudah terkenal itu.

Apabila pelaku usaha dalam menjakan kegian usahanya beriktikad tidak baik (tidak jujur) dengan produksi dan memperdagangkan barang secara pokoknya adanya kesamaan, maka dapat diberikan sanksi pidana sesuai dengan ketentuan Pasal 100 ayat (2) Undang-Undang Nomor 20 Tahun 2016 tentang Merek Dan Indikasi Geografis, yang merumuskan bahwa :

Setiap Orang yang dengan tanpa hak menggunakan Merek yang mempunyai persamaan pada pokoknya dengan Merek terdaftar milik pihak lain untuk barang dan/atau jasa sejenis yang diproduksi dan/atau diperdagangkan, dipidana dengan pidana penjara paling lama 4 (empat) tahun dan/atau denda paling banyak Rp. 2.000.000.000,00 (dua miliar rupiah). ${ }^{15}$

Ketentuan Pasal 100 ayat (2) termasuk dalam ketentuan pelanggaran menirukan artikan setiap orang yang dengan tanpa hak menggunakan merek yang mempunyai persamaan pada pokoknya dengan merek terdaftar milik pihak lain, maka dapat dipidana dengan pidana penjara paling lama 4 (empat) tahun dan/ atau denda paling banyak Rp. 2.000.000.000,00 (dua miliar rupiah).

3. Perbuatan-perbuatan yang dapat mengacaukan publik berkenaan dengan sifat dan asal usul merek

ITerjadinya persaingan tidak jujur apabilapengusaha mencantumkan keterangan tentang sifat dan asal usul barang yang tidak sebenarnya, untuk mengelabui konsumen, seakan-akan barang tersebut memiliki kualitas yang baik karena berasal dari daerah penghasilan barang yang bermutu misalnya asal muasal Kopi Gayo adalah khas dari Nanggroe Aceh Darussalam menjadi Gayo Mountain Coffe, perusahaan asal Belanda tersebut (Holland Coffe B.V). Apabila pengusaha mencantumkan keterangan sifat dan asal usul barang yang tidak benar, untuk mengelabui kon-

$\overline{15} \quad$ Ibid., Pasal 100 ayat (2). 
sumen, seakan-akan barang tersebut memiliki kualitas yang baik karena berasal dari daerah penghasil barang bermutu, maka pengusaha tersebut tidak jujur dalam menjalankan kegiatan usahanya.

Bagi seseorang yang melakukan pelanggaran terindikasi secara geografis yang menunjukkan daerah asal suatu barang dan/atau produk yang karena faktor lingkungan geografis termasuk faktor alam, faktor manusia atau kombinasi dari kedua faktor tersebut memberikan reputasi, kualitas, dan karakteristik tertentu pada barang dan/atau produk yang dihasilkan. Dalam Undang-Undang Nomor 20 Tahun 2016 tentang Merek dan Indonesi Geografis telah memberikan hak eksklusif yang diberikan oleh negarakepadapemeganghak Indikasi Geografis yang terdaftar, selama reputasi,kualitas,dankarakteristikyangmenjadidasa $\mathrm{r}$ diberikannya pelindungan atas Indikasi Geografis tersebut masih ada yang dikaitkan dengan wilayah tertentu dilindungi secara juridis.

Apabila barang dan/atau produk mempunyai persamaan dengan milik pihak lain adanya indikasi geografis, dapat dikenakan ketentuan Pasal 101 ayat (1) Undang-Undang Nomor 20 Tahun 2016 tentang Merek Dan Indikasi Geografis yaitu dengan pidana penjara paling lama 4 (empat) tahun dan/atau denda paling banyak Rp2.000.000.000,00 (dua miliar rupiah). Sedangkan apabilabarang dan/atau produkyang pada pokoknya mempunyai persamaan dengan milik pihak lain adanya indikasi geografis, maka dapat dikenakan ketentuan Pasal 101 ayat (2)Undang-Undang Nomor 20 Tahun 2016 tentang Merek Dan Indikasi Geografis yaitu dipidana dengan pidana penjara paling lama 4 (empat) tahun dan/atau denda paling banyak Rp. 2.000.000.000,00 (dua miliar rupiah).

Dengan adanya ketentuan pemberian sanksi pidana, bagi setiap orang yang menirukan dan memalsukan merek dagang maupun terindikasi geografis terhadap barang atau produk yang diperdagangkan maka akan diberikan sanksi pidana sesuai dengan ketentuan Pasal 100 dan Pasal 101 Undang Nomor 20 Tahun 2016 tentang Merek Dan Indikasi Geografis, pemerintah telah memberikan kepastian hukum bagi sesorang yang hak milik atas mereknya ditiru (dipersamakan secara keseluruhan) atau dipalsukan (dipersamakan yang pada pokoknya/adanya kemiripan) oleh pelaku usaha yang tidak jujur.

Tetapi dalam muatan isi Undang-UndangNomor 20 Tahun 2016 tentang Merek dan Indikasi Geografis, sebagai regulasi yang ada saat ini terkait dengan merek dagang atas produk barang yang dipalsukan atau ditiru oleh pelaku usaha lain yang melakukan dengan tidak jujur belum mengaturnya secara khusus, hanya pengaturan pemberian sanksi pidana bagi merek dagang yang mempunyai persamaan secara keseluruhan atau persamaan pada pokoknya, yang terdapat dalam Pasal 100 dan Pasal 101 Undang-UndangNomor 20 Tahun 2016 tentang Merek dan Indikasi Geografis, belum memberikan perlindunga hukum secara langsung bagi pelaku usaha yang merek dagangnya ditiru dan dipalsukan tersebut.Untuk itu perlu langkah-langkah regulasi yang memberikan kepastian hukum secara yuridis demi memberikan perlindungan hukum bagi pelaku usaha yang merek dagangnya ditiru dan dipalsukan dengan langkah-langkah sebagai berikut :

1. Perlu adanya regulasi secara khusus atas pelaku usaha yang melakukan usahanya dengan membonceng merek dagang terkenal dalam menjalankan usaha tidak jujur.

2. Pemberian sanksi pidana dan/atau denda yang terdapat dalam Undang-Undang Nomor 20 Tahun 2016 tentang Merek dan Indikasi Geografis belum memberikan jaminan perlindungan hukum bagi pelaku usaha yang merek dagangnya ditiru dan dipalsukan oleh pelaku usaha lain yang dalam menjalankan kegiatan usahanya tidak jujur.Perlu adanya pemberian sanksi administrasi berupa penutupan usaha bagi pelaku usaha yang melakukan pelanggaran dalam menjalankan kegiatan usahanya terkait dengan merek dagang. Guna memulihkan nama baik produk yang ditiru dan dipalsukan oleh pesaing usaha tidak jujur tersebut.

3. Perlu adanya regulasi yang mengatur hukum secara tegas dan adil bagi pelaku usaha yang tidak mendaftarkan merek dagangnya, sehingga tidak terjadinya peniruan dan pemalsuan merek dagang. 


\section{Kesimpulan dan Saran}

Kesimpulan yang dapat penulis simpulankan dalam permasalahan penelitian ini adalah

Pemerintah perlu melakukan sosialisasi terkait persaingan usaha yang sehat terhadap merek dagang, dengan cara :

Melakukan edukasi secara mendasar kepada masyarakat khususnya pelaku usaha.

Melakukan kampanye-kampanye mengenai pelanggaran merek atau larangan mengguna- kan merek orang lain atau merek terkenal.

Memberikan pemahanan kepada masyarakat terkait masalah sistem hukum merek dalam melindungi produk indikasi geografis.

Mengadakanpelatihan-pelatihanyangdifokus- kan bagi para pemeriksa merek serta Penyidik Pegawai Negeri Sipil (PPNS) Direktorat Jen- deral Kekayaan Intelektual.

Mengajak Masyarakat Indonesia Anti Pe- malsuan untuk berdiskusi hal kongkritterkait penanganan terhadap pembajakan serta pe- malsuan merek terdaftar.

Adanya pemantauan, evaluasi, dan pembinaan oleh pejabat terkait seperti Direktorat Jenderal Kekayaan Intelektual dan Komisi Pengawasan Persaingan Usaha (KPPU).

Melakukan teguran dan sanksi hukum se- cara tegas bagi para pelaku usaha yang tetap melakukan pelanggaran terhadap kegiatan usahanya.

Apabila terjadi pelanggaran-pelanggaran terhadap persaingan usaha tidak jujur terkait dengan merek dagang, peran pemerintah sangat penting, dimana upaya yang dilakukan pemerintah yaitu melakukan tindakan hukum, pada saat adanya pelaporan yang diduga telah melakukan pelanggaran dalam bisnis persain- gan usaha terhadap merek dagang tersebut. Maka aparat penegak hukum dalam hal ini Polri dan pejabat Penyidik Pegawai Negeri Sipil tertentu dilingkungan kementerian yang menyelenggarakan urusan pemerintahan di bidang hukum diberi wewenang khusus sebagai penyidik sebagaimana dimaksud dalam UndangUndang yang mengatur mengenai hukum acara pidana (KUHAP) untuk melaku- kan penyidikan tindak pidana Merek. Apabila pelanggaran tersebut terbukti, maka Undang- Undang Nomor 20 Tahun 2016 tentang Merek Dan Indikasi Geografis, secara khusus meng- atur pemberian sanksi pidana yaitu termbuat dalam ketentuan Pasal 100 dan 102. 


\section{DAFTAR PUSTAKA}

Djumhana, Muhamad, Hak Milik Intelektual, Sejarah, Teori dan Prakteknya di Indoneia, Bandung : Citra Aditya Bakti, 2003.

Gunawati,Anne, Perlindungan Merek Terkenal Barang danJasa Tidak Sejenis Terhadap Persaingan UsahaTidak Sehat, Bandung : Alumni, 2015.

Hermansyah, Pokok-pokok Hukum Persaingan Usaha di Indonesia, Jakarta : Kencana Prenada Media Group, 2008.

Suryodiningrat, R.M., Aneka HakMilikPerindus- trian, Bandung : Tarsito, 1981.

Thomas Mc. Carthy, Trademark and Unfair Com- petition, 4ed., US : West Group, 2000.

\section{Perundang-Undangan}

Kitab Undang-Undang Hukum Perdata.

Undang-Undang Nomor 5 Tahun 1999 tentang Larangan Praktek Monopoli Dan Persaingan Usaha Tidak Sehat.

Undang-Undang Nomor 20 Tahun 2016 Tentang Merek Dan Indikasi Geografis. 